УДК: $331.1 ; 334$

JEL: N830; M290

\title{
N.P.Drozdova
}

\section{RUSSIAN ARTEL AS AN ORGANIZATIONAL FORM OF PRODUCTION IN THE NINETEENTH AND EARLY TWENTIETH CENTURIES: A NEO-INSTITUTIONAL APPROACH}

St. Petersburg State University, 7-9, Universitetskaya nab., St. Petersburg, 199034, Russian Federation

Artels, some kind of semi-formal association for co-operative labor, were widely spread in Russia right up till early twentieth century. There are different explanations of this phenomenon. Using the New Institutional Economics approach the paper reveals that artels as an organizational form of production that existed mainly due to rather effective solving adverse selection and moral hazard problems.

Keywords: artel, New Institutional Economics, team production, adverse selection, moral hazard, agency costs.

\section{РОССИЙСКАЯ АРТЕЛЬ КАК ОРГАНИЗАЦИОННАЯ ФОРМА ПРОИЗВОДСТВА В ХІХ - НАЧАЛЕ ХХ В.: НЕОИНСТИТУЦИОНАЛЬНЫЙ ПОДХОД}

\section{Н. П. Дроздова}

Санкт-Петербургский государственный университет,

Российская Федерация, 199034, Санкт-Петербург, Университетская наб., 7-9

Артельные формы организации труда и производства существовали в России издревле и применялись в самых разнообразных сферах. В данной статье выявляются причины, способствовавшие относительной устойчивости и распространенности хозяйственных артелей в России.

Важнейшими признаками артельной организации были: договорное начало; добровольность вступления в артель; обязательный личный труд каждого члена в ведении промысла; круговая порука, когда каждый ручался солидарно за всех остальных, а все вместе за каждого. Законодательство об артелях конца XVIII - начала XX в. носило самый общий, рамочный, характер. В нем закреплялись принципы, спонтанно сформировавшиеся в процессе длительного функционирования артелей. Единственное, что постоянно подтверждалось в правительственных указах, касавшихся деятельности артельных организаций, - это необходимость круговой поруки и ответственности членов артели друг за

(C) Санкт-Петербургский государственный университет, 2016 
Russian Artel as an Organizational Form of Production in the Nineteenth and Early Twentieth Centuries...

друга. Формальные правила функционирования артелей дополнялись неформальными, но общераспространенными процедурами.

С позиций новой институциональной экономической теории артельную форму ведения хозяйства можно трактовать как решение проблем, сопряженных с работой в команде. При работе в команде возникают большие трансакционные издержки: организационные, издержки мониторинга и дисциплинирования членов команды, определения их индивидуального вклада в общий выпуск. В трудовой артели довольно успешно были отработаны механизмы снижения такого рода трансакционных издержек, в том числе издержек формирования успешной команды, подсчета (измерения) производительности и вознаграждения, предотвращения возможного оппортунистического поведения.

Мерами предотвращения предконтрактного оппортунизма служили в первую очередь критерии приема в артель: учет имущественного состояния, физических и нравственных качеств будущего члена артели, а также наличие вступительного взноса. Важную роль играли поручительства. Критерии приема в артель обеспечивали своеобразную фильтрацию претендентов. Проблема подачи ложных сигналов отчасти решалась за счет учета места жительства, так как люди хорошо друг друга знали. Факторами, снижавшими вероятность постконтрактного оппортунизма, были круговая порука, принятие решений общим собранием, система оплаты труда и штрафных санкций, выделение специального субъекта мониторинга (старосты, десятника, атамана и т.п.). Функции принципала по распределению задач и контролю поочередно выполняли все члены артели. Широко практиковался взаимный мониторинг.

Трудовые артели в основном получали распространение там, где не требовалось больших затрат капитала, использования сложных видов техники, где труд был однородным и работа могла быть разделена на качественно одинаковые части. При выполнении простых однородных работ практически единственным специфическим активом является человеческий капитал работников, что усиливает возможность оппортунистического поведения. Для решения этой проблемы спонтанно возник соответствующий тип институциональных и контрактных соглашений - артель.

Ключевые слова: артель, новая институциональная экономическая теория, производство в команде, неблагоприятный отбор, моральный риск, агентские издержки.

\section{INTRODUCTION}

The history of artel traces back to its origins in ninth-tenth centuries. Artels, some kind of semi-formal association for co-operative labor, were widely spread in Russia right up till early twentieth century. There was much contemporary literature of Russian authors dealt with different aspects of artel including its organization, typical forms, functioning, performance, and many others. As for publications in English directly addressed to Russian artel they are few. Socio-economic approach to artel is demonstrated in a profound, full of stimulating ideas, and in some way «classical» paper of Norbert Pinkus named «Artel» and published in 1902 in Economic Journal [Pinkus, 1902]. Pinkus examined origin and discussed the principles governing the formation of Russian artels. Among rather resent publications there are papers of Y. Imai [Imai, 1990], J. Bushnell [Bushnell, 1990], and A. Wood [Wood, 1990]. However the method used by the authors is mainly historical. Moreover Bushnell's and Wood's papers are devoted to very specific topics. Imai's paper examines the artels and consumer cooperatives in Russia and the 
Ukraine in the 1860s and early 1870s basing itself on the observations of contemporary Russian authors on this subject.

The existence of artels was explained in different ways. Native writers stated that the Russian person had a specific inherent motivating commitment to collective work in artels. For example V. Vorontsov, a Russian populist (narodnik), specified that «our capitalistic manufacturing must be transformed into a state or artel production»; «our further industrial progress will rest on truly people's principles represented by communes and artels» [V.V., 1882, p. 68, 309] ${ }^{1}$. However M. Tugan-Baranovsky wrote that «despite all profuse talk about Russian people's unusual propensity for working collectively, enthusiasm for associations and artels had no roots in Russia, and that's why it brought no fruitful results. General praising of artels did not result in creating a single, stable artel and did not lead to the emergence of a cooperative movement somewhat similar to that in Europe. The individualistic West with its different political systems turned out to be more tailored to accept artel principles than communal Russia» [Tugan-Baranovsky, 1997 [1907], p. 495-496; 498-499].

According to Pinkus the artel forced into existence 1) in the first instance by economic pressure, i.e. inefficiency of individual efforts due to peculiar geographical features of Russia (inclement and uncertain climate; vast and monotonous surface; lack of fertile soil; inadequate for effective intercommunication river systems; paralyzing influence of the long distances), 2) by Russia's historical vicissitudes, in particular MongolTartar influence, and 3) by curiously complicated problems of ethnography in Russia [Pinkus, 1902, p.489, 493]. Some of his arguments are undoubtedly valid but need to be added one which seems to be decisive in the explanation of persistence of Russian artel in nineteenth - early twentieth centuries. Labor artels, as an institutional form, were a good way of solving a classical teamwork problems and enabled to considerably cut agency costs.

The aim of this paper is to reveal that the existence of artels in Russia was, to a large extent, due to a higher economic effectiveness of this organizational form of economic activity in some spheres. Factors which helped artels come into being and remain relatively stable and common in the historic past are the subject of this investigation. This study is based on empirical descriptions of artels of the second half of the nineteenth century, artels' charters, statutes relating to artels and a wide range of historical literature. Alchian-Demsetz' team production concept [Alchian, Demsetz, 1972] and Jensen-Merckling's agency costs concept [Jensen, Meckling, 1976] are used as an analytical tool.

The first section of the paper describes artel as a form of economic activity in Russia, as formal and informal institution. The second one gives evidence that artel can be interpreted as a way of solving team production problems. The final section summarizes the findings and suggests some implications.

${ }^{1}$ See also: [V.V., 1895a; 1895b]. 


\section{ARTEL AS ECONOMIC ORGANIZATION}

Types of artels. Artels, some kind of semi-formal association for co-operative labor, were widely spread in Russia right up till early twentieth century. There were a lot of artel types carrying out different work: of a spiritual character: religious, entertaining, educational (joint subscriptions to newspapers and books, hire of teachers, etc.); nursing; communal; of thieves; of beggars; economic: agricultural, fishing, production, handicraft, trading, building, etc.

A special role was played by exchange (birshevaya) artels in the the nineteenth century. Their members' duties were diverse. One group of exchange artels provided loading and unloading of goods at the exchange, packed and dispatched various cargoes, guarded warehouses, etc. Besides that, artel members fulfilled other duties for their employers: they worked in offices as assistants and errand boys. Sometimes they were given big sums of money to carry because their employers trusted them. Quite often they did household chores. The members of the other group of exchange artels were employed as clerks and messengers in banks, commercial establishments and in the railway administration.

The main focus of this paper are artels which employed collective work. They include labor artels proper (a group of workers offering their collective services as builders, diggers, loaders, porters, etc. for pay) and production artels of a pure labor type where all workers are owners of the plant and the goods they produce, there are no hired workers, the head is elected by the workers.

Artel as a formal and informal institution. The word 'artel' was used in legislative documents for the first time in the middle of the seventeen century replacing the word 'vataga' (crowd). It was formalized as an institutional economic form in 1799 in Guilds' Charter where in Chapter XIV «On work done by artels» artel members' rights and duties were finally defined. According to the definition formulated in Clause 1, «work or a task which is beyond one worker's capabilities can be done by common consent by a group of workers, and such groups must be called artels» [Ustav Tsekhov, 1799]. Clause 4 also had some important information on artels. It read that «each artel member must be responsible for the incurred damage or losses and guarantee payment».

The artel definition was specified in the 1823 Statute which ran that «artel means that each worker is responsible for everybody in artel and the whole artel is responsible for each worker, they are paid from a common fund (duvan) and work is done collectively» [O vzyskanii 40-rublyovoy poshliny..., 1823, Art. 4]. The same definitions were used in the Trade Charter, and in the nineteenth - early twentieth centuries artels were specified as «associations of workers set up voluntarily to carry out work or production which is beyond one worker's capabilities» [Ustav Torgoviy, 1903, Art. 79].

Labor artel Statute was passed on June 1, 1902 in which labor artels were defined as «partnerships set up to carry out specific work or production as well as provide services by participants' personal involvement at their expense by collective guarantee». A similar definition was given in the Civil Statute [Svod zakonov grazhdanskih, 1906, Art. $\left.2198^{1}\right]$. 
Labor artels were established in accordance with either existing statutes or agreements. Their charters were submitted to the governor for approval and published in local newspapers. Any person, male or female, over 17 years old could become an artel member. But under-21s had no right to participate in management. Artel got an official status if it had 5 members and its charter did not stipulate a greater number of workers. It was managed by the general meeting. Meetings took place only if not less than half of the members were present. Every member had one vote. Decisions were made by a majority of votes. More important decisions required the presence of $2 / 3$ of its members. Membership fees were the same for everybody and could be paid in cash or in kind. If sums paid to the cashier exceeded fees, they were considered as loans. Wages were paid to all members in accordance with the resolution of the general meeting regardless of the sums in each member's account. Artel used its assets to cover all losses and meet liabilities. If artel's assets were insufficient, its members' private property was claimed in its entirety or in the amount specified in the Charter.

All chartered artels enjoyed the rights of entities, i.e. they could buy assets, sign agreements, sue and be sued, set up or take on lease industrial or trade facilities.

Thus, the most important features of artels in Russia were as follows:

- voluntary membership;

- personal involvement in artel's activities binding for all members;

- collective guarantee (krugovaya poruka), i.e. all members shared responsibility for the damage and losses;

- besides that, amendments to the 1823 Guilds Charter stated that anyone wishing to be an artel member must pay an admittance fee.

These formal principles of managing artel's activities supported by the legislation strengthened the rules used by artels at the time and which were full of generalities. The only thing regularly highlighted by various state decrees on objects of management was the necessity of each member to carry responsibility for artel.

As far as artels' structure, relationships among members, their contracts and agreements are concerned, there was hardly any legislation on that, and artels' charters differed significantly from each other. That's why formal principles were supplemented with informal, widely spread procedures spontaneously formed over artels' long history. These principles include taking decisions by a vote at the general meeting, electing management, equality in profit sharing for the same labor input. Admittance criteria were also similar. The following things were taken into consideration: gender; place of residence; age; physical strength; skills; property status; no other jobs; moral qualities (soberness was valued most highly).

These criteria were to provide artel members with work on equal terms in return for their commitment to work in artel's interests. Honest work was also guaranteed by: admittance fee; references (until the admittance fee is fully paid); tests; trial period; penalties; risk of expulsion from artel; collective guarantee. 


\section{SPREAD OF ARTELS}

A lot of modern scientists insist that artels as economic forms were ubiquitous in Russia. In particular B. Mirinov, a historian specializing in social history, is one of them. In his two-volumes investigation of Russian social history he writes that «besides communes in rural and suburban areas, they (peasants $-N$. D.). developed a kindred organizational form, artel, which we see in every place where people are involved in specific activities beyond peasants' and settlement communes» [Mironov, 2003, vol.1, p. 525-526].

But a thorough study of facts makes it possible to conclude that collective labor forms, including artels, were not as common as they are sometimes described. First of all production artel's «natural habitat» was quite narrow and was confined within a) activities of low capital investment, simple homogeneous job and labor with primitive equipment and technology; b) lower classes of population. Artel in its "pure» forms did not survive in other spheres. Secondly the collective forms of labor in Russia were often introduced deliberately and to a considerable degree were connected with the non-economic coercion and propagation. Deliberate creation of labor artels by some enthusiasts required much time, effort and investments from them.

Indeed only two artel types were common and successful in Russia, i.e. butter manufacturing and exchange ones. Exactly these artel types are often referred to when proving that artelnost is inherent in the Russian national character. Let's consider each type in detail.

There were 51 butter manufacturing artels in Russia in 1901; in 1917 their number was 3,000. They were not of a labor type though, because hired workers were engaged in butter manufacturing. Small milk producers owned these artels, managed the manufacturing process personally and collaborated with other owners only when selling milk. Consequently, a butter manufacturing artel is a selling cooperative, a processing partnership. The butter belonged not to the producers but to the milk suppliers. Profits were divided in proportion to the supplied milk, not by shares [Tugan-Baranovsky, 1989 [1919], p. 102]. Such artels emerged in Russia in late 1860s. They were initiated by N. Vereshchagin, a gentleman by birth, who borrowed the idea from Switzerland and had been introducing it actively in Russia since $1865^{2}$. The first artels didn't live long. One of the reasons of their failure was that peasants were not prepared for them. They gave no credence to this economic form. Their attitude to innovations was that of opposition. That's why Vereshchagin made every effort to convince them of advantages of dairying artels. Butter and cheese manufacturing artels started springing up again only in late 1890s and became common only when peasants came to understand that it was a paying business, and it had advantages over other forms, including capitalistic.

As for exchange artels regulations on them were passed on June 16, 1905. They were quit similar to the Labor Artel Statute. In accordance with Clause 1, «exchange artels aim at carrying out work related to acceptance, dispatch and storage of goods as well as

\footnotetext{
2 See [Vereshchagin, 1999 (1865); 1999 (1870); Shatilov, Vereshchagin, 1869].
} 
fulfilling office tasks and trading with organizations and individuals» [O pravilakh dlya birzhevykh arteley..., 1905]. Exchange artels could function only in accordance with the charter which was approved by the Exchange Committees. Thus, exchange artels' activities were based on clearly defined rules, meeting of liabilities being guaranteed collectively by the insurance policy. At the same time they hired outside laborers, their members were paid by the day and by the piece and due to these features these associations were not artels in their true sense because they did not meet all artel's requirements. As a consequence exchange artels could not be considered as «artel», which was officially recognized by the 1823 Statute [O vzyskanii 40-rublyovoy poshliny..., 1823]. And the fact that «they are, really, artels only in names» was absolutely correctly stressed by Pinkus [Pinkus, 1902, p. 487].

As far as labor artels which used collective work are concerned, they became common only in the spheres of activity which didn't require big investments, complicated machinery, where work was homogeneous and could be divided into equal parts and done by individual workers, in other words, where people simply cooperated to do a job. Artels were mainly formed to produce goods in the absence of expensive machinery and great technical expertise [Yarotsky, 1898, p. 22]. N. Kalachov described artel as part of the common people's life and relationships [Kalachov 1999 (1864), p. 308]. The last aspect was also admitted by Pinkus [Pinkus, 1902, p.496] who defined artel 'as an association for co-operative labour formed by the lower classes of the population themselves usually under pressure of extreme need and therefore strongly imbued with that spirit of local solidarity which the conditions of life have developed in the Russian, and also ruled by the customs and laws of the local Mir, the Russian village community'3.

Production artels of a pure labor type were very rare everywhere. Great Britain had only one artel of this type in 1916, whereas Germany had none. There were about a hundred small production artels in France due to the support from the government bodies, public institutions or individuals. Only big Italian agricultural artels achieved success without any support. But their aim was to fight unemployment, and their members had more than one job. In Russia, production labor artels didn't become common either. According to I. Sapozhnikov [Sapozhnikov, 1916, p. 14], there were only

${ }^{3}$ It is necessary to stress that artel and peasant commune as organizational forms of production were quite different. In Russian peasant commune property rights regimes were of different types. There were communal property rights in arable land, hayfields, mills, wharfs. Arable land and hayfields were subjected to equally repartitions according to definite criteria. Mills and wharfs were usually leased with income at commune's disposal. Common property resources (the commons) included wasteland, grazing land, rivers, woodland. However good-quality woodland was usually parceled out. Inherited by the family members plots of land attached to houses in the village used for growing vegetables, fruit, and so on. There were also obligatory public tillage (obshchestvennye zapashki), when some communal arable land was cultivated collectively and the crop was stored in so-called «storage shops» (zapasnyie magaziny) as a form of insurance against crop failure. Egalitarian principle concerned only land distribution not income because household allotments were cultivated by users individually. Moreover equal repartition was not "spontaneous order" but an institutional answer on governmental tax policy, namely equal poll tax imposed by Peter I and collective responsibility to pay taxes. Collective responsibility was almost outdated by 1900 . About $99 \%$ of communes did not use it. 
16 artels in Moscow in 1908, 60 in 1909, and about 115 by 1916 . However, none of them developed into a big enterprise. They were small workshops which either died or turned into small capitalist enterprises. Sapozhnikov thinks that shortage of working capital and mainly absence of organizational, technical and institutional support caused the failure of those artels.

As far as agricultural artels are concerned, of all types of cooperation peasants could form, these were the rarest. As it is written in one of the early XX century articles on agricultural artels, «at present we have not more than a few dozens of big agricultural artels in Russia which would buy or rent land collectively with a view to working jointly on it» [Gorovaya, 1916, p. 8-9]. This phenomenon was caused, according to Gorovaya, by two things. Firstly, artel members often had to give up habits and propensities acquired in childhood and inherited from the previous generations. They had to conform to the actions and desires of their fellow-workers, but neither household possession nor the compulsive order in the commune taught peasants to be compliant. «Sometimes they champion their interests passionately but at other times they submit to the decision made by the majority of artel members out of necessity» [Gorovaya, 1916, p. 6]. Secondly, differences in peasants' property status, capacity for work and intellectual faculties hampered artels' activities.

Agricultural artels' existence, like that of butter manufacturing ones, was mainly due to enthusiasts' activities. It was Nikolai Levitsky who organized the first agricultural artel in Russia in 1896 and who was called 'artel's batko' (ideological leader) by peasants. On the other hand he pointed out that labor artels in general and production artels in particular were the most difficult types of cooperation to put into practice. «It is not an easy task. It requires that peasants have plenty of stamina, developed self-consciousness and great initiative» [Levitsky, 1916, p.4]. He pointed out that the society rejected this form of production organization, that «artels were the most neglected form of cooperation» unlike consumer, credit or loan-saving societies which were under the patronage of the community, zemstvo or state.

Only one big production artel lived long in Russia and proved to be viable. It was a knife-producing artel in the village of Pavlovo which was set up in 1893 and supported by individuals, public institutions and the state. However, Pavlovo artel gave so few benefits to its members that hired workers did not want to join it [Tugan-Baranovsky, 1989 [1919], p. 207].

These facts prove once again that Russian people did not have any special propensity for working in artels as a way to meet their needs to work communally, and that the main reason for joining them was of economic nature. Collective work was only a means which enabled people to make money in initial conditions and types of jobs.

In practice, production artels operating both abroad and in Russia were either ineffective or turned into capitalist enterprises, which is demonstrated quite convincingly in one of the articles of the late XIX century [P-r, 1897]. Many researchers pointed out that a lot of artels which originally were workers' unions turned into entrepreneurs' unions. Hands were hired to do work, whereas artel members managed them and 
gained profits. Thus, the very essence of artel as a workers' union was destroyed. In this connection, wage labor in artels was restricted by law. Artels' charters had to stipulate terms and the procedure of employment as well as the number of hired workers. Hired workers were allowed to work in artels only on a temporary basis in exceptional cases. These regulations artificially confined evolution of artels to capitalistic concerns and conserved this primitive form of economic activity.

\section{LABOR ARTELS AS TEAM PRODUCTION}

Work in artels can be considered as teamwork. A team is a group of individuals with common aims who divide work among themselves and carry responsibility for achieving certain results. Team members are interdependent because to achieve common aims they need the results of the work done by their fellow-workers. The team's main difference from traditional formal work groups is synergy effect (i.e. total amount of work done by the team exceeds the sum of their individual work). Teamwork is widely used at present. Teams are formed when it is economically beneficial, regardless of which culture, collective or individualist, prevails in the society.

Using D. McIntoch-Fletcher's team criteria artel can be classified as an intact team type in contrast to a cross-functional one. An intact team is usually a production unit or a long-standing group of workers producing a certain product or service. It can have a leader who is not a team member, and whose duty is to coordinate work and secure order. In other cases the team can have a leader from within. In some cases team members can play the leading role in turn. McIntoch-Fletcher [McIntoch-Fletcher, 1996] points out that quite developed mature autonomous intact teams can operate as small enterprises.

There are four team types according to their aims: consultative (dealing with management); production (teams of production workers, miners, repairmen, etc.); project (research and planning groups, etc.); action (sport teams, for example). From this point of view, artel can be defined as a production team.

The problem of teamwork production and methods of monitoring was analyzed in a well-known article by A. A. Alchian and H. Demsetz [Alchian, Demsetz, 1972]. Teamwork entails big transaction costs: organizational, of monitoring, disciplining, assessing each member's contribution to the production output. «Team production will be relied upon... if there is a net increase in productivity available by team production, net of the metering cost associated with disciplining the team» [Alchian and Demsetz, 1972, p. 780].

Alchian-Demsetz' study was a starting point for a number of articles, including an article by M.C. Jensen and W.H. Meckling [Jensen, Meckling 1976] in which they introduce the notion of agency costs. According to them, in most agency relationships the principal and the agent incur positive costs of monitoring as well as bonding costs in a monetary or non-monetary form. Besides, there are the principal's residual losses as a result of discrepancies between the agent's solutions and the solutions that could have maximized the principal's financial standing [Jensen, Meckling, 1976, p. 308]. 
In his paper 'Teamwork and moral hazard', B. Holmstrom [Holmstrom, 1982] demonstrated that the free rider problem could be solved to a great extent if ownership had been at least partially separated from the workers, which gives priority to capitalist firms over partnerships. Labor contribution rating system can help to overcome a moral hazard threat because it divides risks in a more favorable way. Of great importance are the following questions: whether the agents can come to a mutual agreement while using this work assessment method; what monitoring methods are used; how the output is divided among team members, including the subject of monitoring, in order to work out the most effective incentives for work [Holmstrom, 1982, p. 338-339].

The structure of principal-agent relationships in artels was quite complicated. On the one hand, the owner who hired artel workers to do a job, played the role of the principal while artel was an aggregate agent. At the same time the owner quite often signed agreements with individual artel members when, for example, he hired them himself, as it was in barge hauling artels, or if he employed them to do some household chores, which was common practice in exchange artels. On the other hand, artel itself served as the principal towards artel members, but at the same time they jointly controlled artel activities because important decisions were made at the general meeting.

Labor artels had quite successful mechanisms of lowering different transaction costs resulting from team production:

- by preventing possible opportunism;

- by measuring productivity and remuneration;

- by solving a free rider problem when one member's shirking affects the rest of the team.

Opportunistic behavior in artels. Opportunistic behavior, «self-interest-seekingwith-guile» or calculated dishonesty according to the definition given by O.E. Williamson [Williamson, 1996, p.378], implies pursuing one's own goals, sometimes perfidiously and unethically, which interfere with an institution's interests. Postcontracting opportunism becomes apparent in the form of shirking, extorting and blackmailing. Consequently, opportunistic behavior can testify to disregard of collective interests. Discipline (labor, technological, economic, etc.) is crucial in cooperation. Was there any discipline in artels? Unfortunately, it is impossible to estimate the actual scale of opportunistic behavior in artels.

For example, no special penal books in exchange artels preserved. To protect artel's reputation after the year was over, and all payments made, artel's financial books were destroyed making it impossible to see whether any member had been fined or not [Kalachov, 1999 [1864], p. 322]. However, the destruction of the books in itself testifies to the problem of improper attitude to work. Embezzlement was the main problem in exchange artels' activities. Newspapers of the early XX century were full of embezzlement facts, misappropriated sums amounting to 200,000 roubles, which was a huge amount at the time. That's why one of the reports made at the first all-Russia convention of exchange artel representatives was on reinforcement of responsibility for embezzlement [Vserossiysky s'ezd predstaviteley..., 1912]. 
Opportunistic behavior was quite common practice in artels. In his paper on artel development in Russia, G. Petrov points out that attempts to make artels common failed. They failed to overcome negative features inherent in other forms of cooperation. Minutes of general meetings mentioned quarrels, envy and favoritism, lack of selfconsciousness and self-discipline, and poor attendance at meetings. Because of that, management had to either impose penalties or pay for attending meetings. Not all artel members worked for it. Plenty of them used artel's raw materials for work somewhere else, sometimes for artel's competitors [Petrov, 1917, p. 66-67].

In butter-manufacturing artels members spoilt milk by adding water, some other substances, by no keeping within technological processes. Even such an adept artel's advocate as M. Slobozhanin stated that artels' reality was a far cry from their ideals embodied «people's aspirations for a better financial standing, freedom, equality, democracy, consciousness, dignity, friendship, fraternity, etc.» [Slobozhanin, 1919, p. 14].

Researchers of XIX - early XX centuries put forward some reasons why production artels did not succeed. They were summarized by Tugan-Baranovsky [TuganBaranovsky 1989 (1919), p. 196] and were as following: lack of discipline among artel members; the employer's absence and the elected leader's weak authority with the result that his decisions are ignored, with workers putting their interests first; the leader selected from within, as a rule, does not have enough expertise and management skills; workers' technical backwardness, weak propensity for innovations and implementation of modern technology; workers do not tend to use new production methods; no freedom in selecting staff. Staff consists only of artel members. A new member represents a threat to the benefits which artel has due to its old members' effort. That's why, if artel is successful, introduction of new members leads to old members' losing part of their benefits.

Prevention of opportunist behavior in artels. Admittance criteria, such as a property status, moral qualities of a member-to-be and an admittance fee which was, as a rule, quite high, were preventive measures against opportunist behavior before signing a contract with the worker - screening mechanisms. For example, admittance depended on «paying, on average, up to 1,000 silver roubles [Kalachov, 1999 (1864), p. 320, 324]. Thus, to become a member of Metelkin artel at St. Petersburg's Marine Exchange, a candidate had to pay a fee of 900 roubles to artel in 1812, 200 roubles paid at the time of joining it [Kalachov, 1999 (1864), p.350]. At that time it was a huge amount of money which could be earned only by a hard working person with entrepreneurial skills. The fact of having this sum signalled that the candidate had all the necessary qualities.

The problem of dealing with false information about candidates was partially solved by finding out the truth in the neighborhood where they lived because they had to give information on the place of residence. References also played an important role. Thus, candidates were, to some extent, screened because of admittance criteria. Besides being a signal, the admittance fee, according to Jensen-Meckling's terminology, played the role of bonding costs, as the member who was about to be expelled from artel because of his inadequate behavior, lost a part or the whole sum of the collateral. 
Collective guarantee was a powerful factor which undoubtedly made postcontractual opportunist behavior less probable. ${ }^{4}$ But it could not prevent it completely. That's why artel members were paid accordingly: they could be punished for their demerits in accordance with artel rules or resolutions passed at the general meeting. The inflicted punishments included fines, corporal punishment, removal from work and even expulsion. The list of demerits and the size of fines varied in different artels. For example, in Metelkin artel which was mentioned above, a member had to pay a 5-rouble fine for being absent from work, for abusing other members, for not being as hard working as them, or being drunk at work. If a member had an additional job without having let artel know about it, he had to pay 25 roubles [Kalachov, 1999 (1864), p. 350]. One of artels in 1810 had a rule of imposing a big fine on a member causing trouble between the employer (or 'master' as members of artel called him) and the members [Kalachov, 1999 (1864), p. 349]. Some artel charters ordered its members to inform on their fellowworkers if they misbehaved. If they did not do that, they were also severely punished. Such practice seemed to be common because this type of mutual monitoring considerably lowered costs related to it.

One of the ways of fighting shirking suggested by Alchian and Demsetz involves selecting of a special subject who monitors the team's performance. However, the problem is that the subject can shirk himself. There was a controller in each artel (starosta (headman), desyatnik (charge-hand), ataman) who besides getting his share of pay, as a rule, was paid some extra money as a bonus for his work, but was fined if he misbehaved.

Thus, exchange artels were run by persons, either selected from within who did it in turn, or elected at the general meeting. The «manager» (starosta) was usually elected for a one-year period. If he coped with his duties well, he could be re-elected for a new term. His duties included securing artel's money, assigning tasks to members, checking their completion, imposing petty fines. The elected starosta was specially remunerated for his work whereas the person who played this role in turn, did not get any extra pay for that.

Fishing and hunting artels always had a head who was paid four to seven times more than an ordinary member. Barge hauling artels paid equally to all members including the elected desyatnik for their work but he was paid a special remuneration for additional duties.

Thus, artel can be defined as a coalition of agents with a revolving leadership structure where agents participated in profit making as well as took turns in playing the role of the principal. Rotation of agents in the principal position with the authority delegated to them to control the other members' actions resulted in exchanging reliable information, creating the necessary prerequisites for strengthening trustworthy relationships among agents and developing cooperation, which in turn led to creating an «associative atmosphere» within the organization which prevented opportunist behavior and maxi-

${ }^{4}$ Grameen bank set up in Bangladesh by a 2006 Noble Prize winner, Muhhamad Unus, is a good modern example of giving out loans, taking into account collective guarantee as a tool to solve the problem of adverse selection and prevent agents' opportunism (see: [Morduch, 1999]). 
mized feasibility [Williamson, 1975, pp. 38, 44]. Personal or collective contracts with an employer served as an additional protection from opportunism in artels, e. g. there were detailed laws regulating relationships among barge haulers and ship owners. Thus, conflicts could be settled both unofficially and in court, shipping and arbitrary courts being in charge of that.

Measurement cost cuts in artels. Payment for work done by artel members was made in accordance with the capital or effort contributed by each of them. Profits were usually divided equally among the members, fines being deducted after that. Sometimes the amount of labor input, on rarer occasions the level of expertise, were taken into account to calculate workers' pay. Measuring of individual input entailed transaction costs. Cutting of these costs was mainly achieved by setting up artels to carry out simple one-type jobs. Work could be either divided into quantitatively equal parts and assigned to separate workers, as it was done for loading and unloading, digging, mowing, forest cutting jobs, or it simply required joint effort, as in barge hauling.

Another important thing was that labor, as a production factor, was relatively homogeneous because physical strength and skills were taken into account when hiring artel members. This team formation principle was common everywhere. According to A. Engelgardt, "peasants do not agree to mow collectively by forming a line». It is possible only when artel is formed by $4-5$ workers with similar capabilities» [Engelgardt, 1956 (1897), p. 290].

The discussion of agency costs issue would be incomplete without consideration of interrelationship between artel's organizational structure and the decision process. E. Fama and M. Jensen [Fama, Jensen, 1983] put forward a question of how to divide among the agents such functions as: 1) decision management (decision initiation and implementation); 2) decision control (decision ratification and monitoring), and 3) a residual risk bearing in order to ensure economic efficiency. According to them, in a small, non-complex organizations it is reasonable to make one or several agents responsible for these functions because if the number of residual claimants is great, their participation in decision control entails considerable costs. Artels were for the most part small noncomplex organizations. But the above-mentioned functions were not separated here. All three functions were placed in the hands of the same individuals. The key reason was collective guarantee. All members carried risk equally being responsible for the damage and losses. In return all members had equal rights for residual claims and the management and control of important decisions at general meetings. Non-separated functions of risk bearing and decision-making lowered the profits, but they were possibly compensated by cutting metering costs and less opportunism due to collective guarantee.

\section{CONCLUDING REMARKS}

Analysis reveals that existence of artels in Russia was, to a large extent, due to a higher economic effectiveness of this organizational form of economic activity in some spheres. Principal-agent and team production approaches highlight that Russian artel 
as an economic organization can be interpreted as an effective way for solving adverse selection and moral hazard problems. The behavior of artels' members was rational and quite individualistic.

Labor artels were mainly confined within activities of low capital investment and uncomplicated machinery. Work was homogeneous and the job could be divided into quantitatively equal parts. Practically, the only asset used to carry out simple homogeneous work was workers' human capital, which could lead to extra opportunistic behavior. That's why artel as a contract-based institutional type came into being to control it.

Production artels in Russia were not common. They did not live long. A lot of the nineteenth - early twentieth century researchers considered long-term cooperation of producers and artels completely unpractical in Russia. Even those who believed in their future stressed the necessity of coercing people who worked by themselves into these economic organizations. It was also important that the government, local self-government bodies (zemstva), and individual sponsors should support them. The researchers involuntarily pointed out that they were of contradictory character. So one shouldn't exaggerate the role of artel in the process of Russian development.

\section{References}

Alchian A.A., Demsetz H. Production, Information Costs, and Economic Organization. American Economic Review, 1972, vol. 72, no. 5, pp. 777-795.

Bushnell J. The Russian Soldiers' Artel, 1700-1900: A History and Interpretation. Land Commune and Peasant Community in Russia: Communal Forms in Imperial and Early Soviet Society. Ed. by R. Bartlett. New York, St. Martin Press, 1990, pp. 376-394.

Engelgardt A. N. (1897) Iz Derevni. 12 Pisem: 1882-1887 [From a Village. Twelve Letters: 1882-1887]. Moskva, Sel'hozgiz Publ., 1956. (In Russian)

Fama E., Jensen M. Separation of Ownership and Control. Journal of Law and Economics, 1983, vol. 26, no. 2, pp. 301-325.

Gorovaya N. Zemledelcheskaya artel [Agricultural Artel]. Artelnoye delo, 1916, no. 7, pp. 5-12; no. 8-9, pp. 29-37. (In Russian)

Holmstrom B. R. Moral Hazard in Teams. Bell Journal of Economics, 1982, vol. 13, no. 2, pp. 324-340.

Imai Y. The Artel' and the Beginnings of the Consumer Cooperative Movement in Russia. Land Commune and Peasant Community in Russia: Communal Forms in Imperial and Early Soviet Society. Ed. by R. Bartlett. New York, St. Martin Press, 1990, pp. 363-375.

Jensen M.C., Meckling W.H. Theory of the Firm: Managerial Behaviour, Agency Costs and Ownership Structure. Journal of Financial Economics, 1976, vol. 3, no. 4, pp. 305-360.

Kalachov N. V. Arteli v drevney i nyneshney Rossii [Artel in the Ancient and Present-Day Russia]. Kooperatsiya. Stranitsy istorii [Cooperation. Pages of History]. Vol. 1, Book 1. Moskva, Nauka Publ., 1999 (1864), pp. 308-346. (In Russian)

Levitsky N. Budem zhit' [We Will Live]. Artelnoye delo, 1916, no. 6, pp. 1-6. (In Russian)

McIntoch-Fletcher D. Teaming by Design: Real Team for Real People. New York, McGrow-Hill Publ., 1996.

Mironov B. N. Sotsialnaya istoriya Rossii perioda imperii (XVIII - nachalo XX v.): Genezis lichnosti, demokraticheskoy sem'i i pravovogo gosudarstva [The Social History of Imperial Russia (the 18th - the Beginning of the 20th century): The Genesis of Personality, Democratic Family, Civil Society, and the Rule of Law]. Vol. 1-2. St. Petersburg, Dm. Bulanin Publ., 2003. (In Russian) 
Morduch J. The Microfinance Promise. Journal of Economic Literature, 1999, vol. 37, no. 4, pp. 15691614.

O pravilakh dlya birzhevykh arteley [On the Rules for Exchange Artels]. Polnoye sobraniye zakonov Rossiyskoy Imperii [The Complete Collection of the Laws of the Russian Empire]. Code 3d. Vol. XXV. Part I. June 16, 1905, no. 26439. (In Russian)

O vzyskanii 40-rublyovoy poshliny s artelshchikov, nakhodyashchikhsya pri Sankt-Peterburgskoy birzhe i buyanakh [On the Collecting of 40-ruble Fee from Artel Dockworkers Located at the St. Petersburg Exchange and the Places for Unloading Ships]. Polnoye sobraniye zakonov Rossiyskoy Imperii [The Complete Collection of the Laws of the Russian Empire]. Code 1st. Vol.XXXVIII. September 11, 1823, no. 29607. (In Russian)

Petrov G. P. Promyslovaya kooperatsiya i kustar' [Craft Cooperation and Craftsman]. Moscow, Pechatnya S.P. Yakovleva, 1917. (In Russian)

Pinkus N. Artels. The Economic Journal, 1902, vol. 12, no. 48, pp. 485-500.

P-r [Potresov A. N.]. Artelnaya epopeya [Artelnaya Epopee]. Novoye slovo, 1897, Book III, November, pp. 24-51. (In Russian)

Sapozhnikov I.Z. Voprosy kredita i instruktirovaniya v moskovskikh artelyakh [Credit and Instruction Issues in Moscow Artels]. Artelnoye delo, 1916, no. 2, pp. 14-20. (In Russian)

Shatilov I., Vereshchagin N. V. O merah k razvitiyu $v$ Rossii molochnogo hozyajstva na artel'nom nachale [On the Measures for the Development in Russia of Dairy Farms Based on Artel Principles]. [Moskva], University Press (Katkov and $\mathrm{C}^{0}$ ), 1869. (In Russian)

Slobozhanin M. Istoricheskoye razvitiye idey artelnogo dvizheniya [Historical Development of the Artel Movement]. [Petrograd], Kustaresoyuz, 1919. (In Russian)

Svod zakonov grazhdanskih [Civil Code]. Svod zakonov Rossiyskoy Imperii [The Digest of Laws of the Russian Empire], 1906, vol.X, part I. (In Russian)

Tugan-Baranovsky M. (1907) Russkaya fabrika v proshlom i nastoyashchem. Istoricheskoye razvitiye russkoy fabriki $v$ XIX v. [Russian Factory in the Past and Present. The Historical Development of the Russian Factory in the 19th Century]. Moscow, Nauka Publ., 1997. (In Russian)

Tugan-Baranovsky M.I. (1919) Sotsialniye osnovy kooperatsii [Social Foundations of Cooperation]. Moscow, Ekonomika Publ., 1989. (In Russian)

Ustav torgoviy [Trade Charter]. Svod zakonov Rossiyskoy Imperii [The Digest of Laws of the Russian Empire], 1903, vol. XI, part II. (In Russian)

Ustav tsekhov [Guilds' Charter]. Polnoye sobraniye zakonov Rossiyskoy Imperii [The Complete Collection of the Laws of the Russian Empire]. Code 1st. Vol. XXV. November 12, 1799, no. 19187. (In Russian)

V.V.[V.Vorontsov]. Artel v kustarnom promysle [Artel in the Handicraft Industry]. St. Petersburg, V. Kirshbaum's Publishing House, 1895a. (In Russian)

V. V. [V. Vorontsov]. Artelniye nachinaniya russkogo obshchestva [Artisanal Beginnings of Russian Society]. St. Petersburg, M. Stasyulevich's Publishing House, 1895b. (In Russian)

V.V. [V.Vorontsov]. Sud'by kapitalisma v Rossii [The Fate of Capitalism in Russia]. St. Petersburg, M. Stasyulevich's Publishing House, 1882. (In Russian)

Vereshchagin N. V. (1865) Vozmozhny li krestyanskiye syrovarniye arteli v Rossii [Can There Be Cheese-Making Peasant Artels in Russia]. Kooperatsiya. Stranitsy istorii [Cooperation. Pages of History]. Vol. 1. Book 1. Moskva, Nauka, 1999, pp. 459-462. (In Russian)

Vereshchagin N. V. (1870) O rasprostranenii artelnogo syrovareniya v Rossii [On the Extension in Russia of Cheese-Making by Artels]. Kooperatsiya. Stranitsy istorii [Cooperation. Pages of History]. Vol. 1. Book 1. Moscow, Nauka Publ., 1999, pp. 484-488. (In Russian)

Vserossiysky s'ezd predstaviteley birszevykh arteley, Pervyj. St. Petersburg, 1912. Doklady [The First AllRussian Congress of Exchange Artels' Representatives. St. Petersburg. 1912. Reports]. St. Petersburg, N. Ya. Stojkova's Publishing House, 1912. (In Russian)

Williamson O.E. The Mechanisms of Governance. New York, Oxford University Press, 1996. 
Russian Artel as an Organizational Form of Production in the Nineteenth and Early Twentieth Centuries...

Williamson O. E. Markets and Hierarchies: Analysis and Antitrust Implications. New York, Free Press, 1975.

Wood A. Administrative Exile and the Criminals' Commune in Siberia. Land Commune and Peasant Community in Russia: Communal Forms in Imperial and Early Soviet Society. Ed. by R. Bartlett. New York, St. Martin Press, 1990, pp. 395-414.

Yarotsky V. Predpriyatiye [The Enterprise]. Entsyklopedicheskyi slovar. Vol.XXV. Ed. by I.E. Andreevskyi. St. Petersburg, F. A. Brokgauz and I. A.Efron Publishing House, 1898, pp. 19-22. (In Russian)

For citation: Drozdova N. P. Russian Artel as an Organizational Form of Production in the Nineteenth and Early Twentieth Centuries: A Neo-Institutional Approach. Vestnik of Saint-Petersburg University. Ser. 8. Management, 2016, issue 2, pp. 62-77. DOI: 10.21638/11701/spbu08.2016.203

Статья поступила в редакцию 15 марта 2016 г.; принята к печати 20 апреля 2016 г.

Контактная информация

Дроздова Наталья Петровна - кандидат экономических наук, доцент; ndrozdova@gsom.pu.ru

Drozdova Natalia P. - Candidate of Economic Sciences, Associate Professor; ndrozdova@gsom.pu.ru 